\title{
INTESTINAL CRYPTOSPORIDIOSIS. ASSOCIATION WITH PNEUMOCYSTIS CARINII, CYTOMEGALOVIRUS AND CANDIDA SP. INFECTIONS.
}

\author{
K. I. R. COELHO, S. A. MAEDA \& M. E. A. MARQUES
}

\section{S U M M A R $\mathbf{Y}$}

This is a case report of intestinal cryptosporidiosis diagnosed in histological specimen collected from autopsy. The patient was a child of 5 months admitted to the hospital with severe acute diarrhea associated with Pneumocystis carinii pneumonia, cytomegalic sialadenitis, oral and dermal candidiasis. The presence of multiple opportunistic infections in this case indicated immunodeficiency state.

Cryptosporidium sp is a possible etiology of acute diarrhea in both immunodeficient and immunocompetent patients and has to be searched for at autopsy when diagnosis was not possible "in vivo".

KEY WORDS: Immunodeficiency; Diarrhea; Cryptosporidiosis.

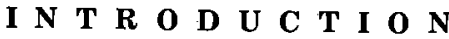

Cryptosporidiosis is a frequent protozoan intestinal infestation affecting guinea pigs, turkeys, mice, calves and other animals; extra intestinal cases are described in animals but are very uncommun in human beings ${ }^{6}$. The parasite is a tiny organism of $2 \mu \mathrm{m}$ to $6 \mu \mathrm{m}$ that adheres to the microvillous border of enterocytes.

Human infestation by Cryptosporidium sp has been described in immunologically compromised patients chiefly in acquired immunodeficiency syndrome (AIDS); therefore cryptosporidiosis has been considered an opportunistic in fection along with Pneumocystis carinii, Cytomegalovirus, Candida albicans, Cryptococcus neoformans, Entamoeba histolítica and Herpesvirus $^{2}$. As a consequence, human cryptosporidiosis has been receiving more attention nowadays, and cases associated with mild and selfli- mited diarrhea in immunocompetent patients have been recently described ${ }^{1,3,10}$.

The main diagnostic method in the past was intestinal biopsy and histological detection of the protozoan but recently it has been successfully replaced by identification of the oocysts in fecal flotation?.

In Brazil there are two reports about cryptosporidiosis and acute diarrhea in the North ${ }^{4}$ and Northeast ${ }^{11}$, no cases having been reported from the South.

\section{CASE REPORT}

The patient was a five-month-old girl who was hospitalized for having had severe diarrhea, vomiting and malaise during the last 12 days.

Address for correspondence: Dra. Kunie Iabuki R. Coelho. Departamento de Patologia da Faculdade de Medicina de Botucatu. CEP 18600 Botucatu, SP., Brasil. 
She was presented with dyspnea and cyanosis at the moment of hospitalization and in about 12 hours progressed to respiratory failure and death; interstitial pneumonia was the clinical and radiological diagnosis.

The child had been breast-fed during the first 3 months of her life, and then bottle. fed. Since then she started having repeated upper respiratory infections. During the last 12 days she had oral and dermal candidiasis, clinically diagnosed. She died and the autopsy was performed.

The child had the normal height for age (60 $\mathrm{cm}$ ), a mild emaciation and mucocutaneous paleness; the body weight was $5.500 \mathrm{~g}$.

Grossly the whole lung was congested, subcrepitant and on sections there was a slight ooze of frothy fluid characterizing interstitial pneumonia. The pleura was smooth without effusions.

Pneumocystis carinii was confirmed by light microscopy (Fig. 1).

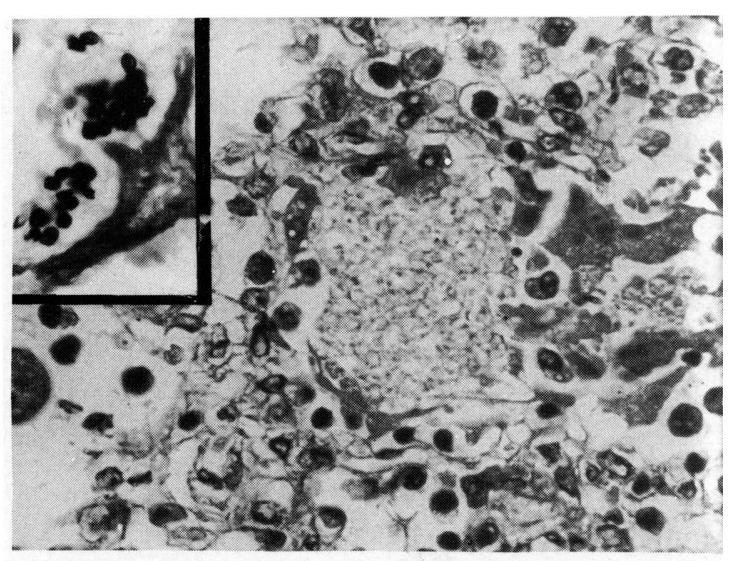

Fig. 1 - Lung with Pneumocystis carinii pneumonia. H \& E 400x. Inset - Gomori staining 400x.

Intestinal cryptosporidiosis (Fig. 2) and cytomegalic sialadenitis (Fig. 3) were the main histological findings, associated with extensive lymphoid depletion in lymph nodes, spleen and thymus. Thymic size was small weighing $9 \mathrm{~g}$; histologically there was no structural change but hypoplasia without fibrosis.

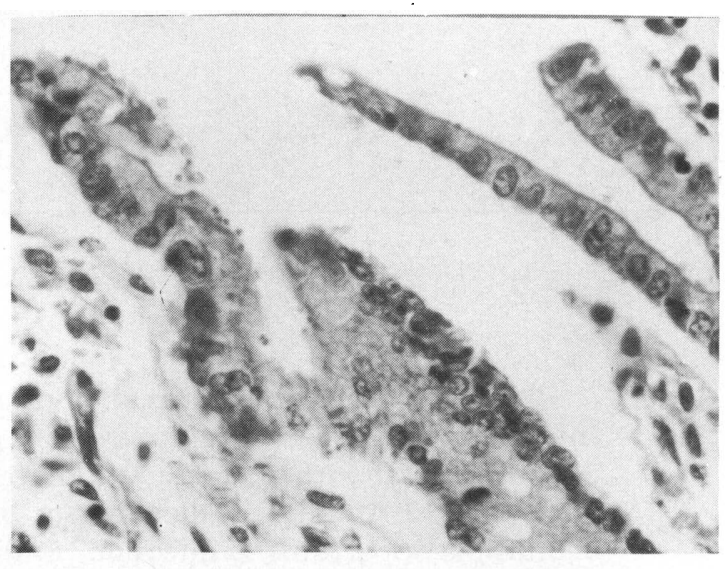

Fig. 2 - Small intestine with Crystosporidium, sp on the brush border. H \& E 400x.

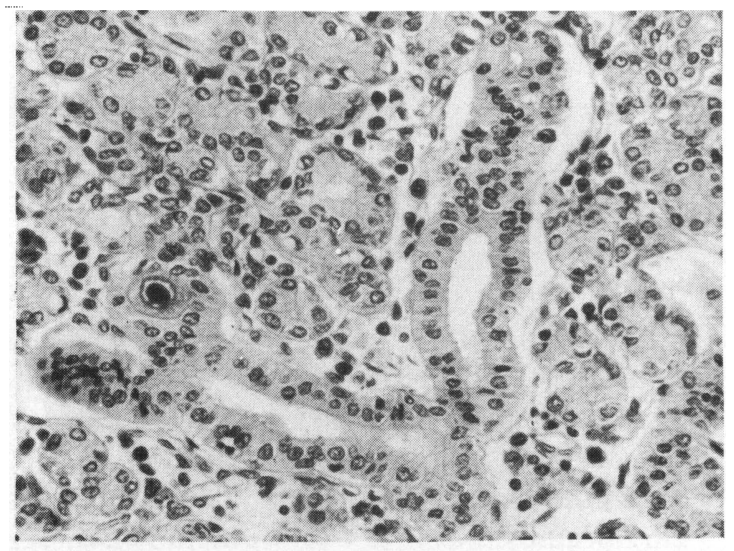

Fig. 3 - Salivary gland showing cytomegalovirus inclusion and sialadenitis. H \& E 250x.

After histological diagnosis of cryptospori diosis, samples of intestinal mucosa from paraffin blocks were taken and processed for electron microscopy; trophozoits (Fig. 4) and macrogametocytes (Fig. 5) were found.

\section{DISCUSSION}

This was the first case of intestinal cryptosporidiosis found in our laboratory. Since authors 


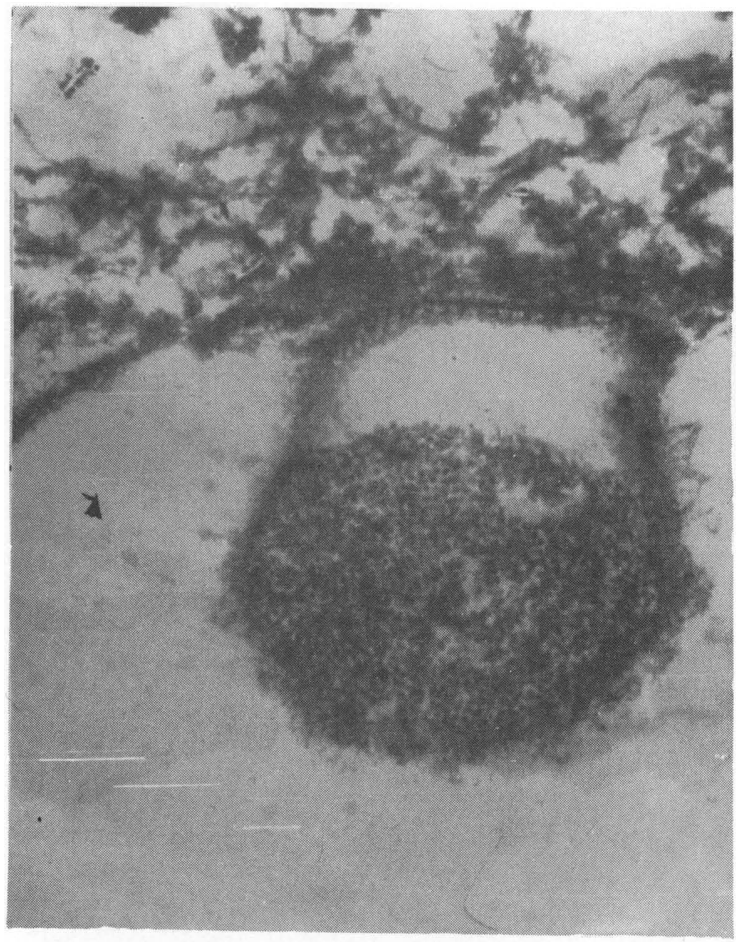

Fig 4 Cryptosporidium, sp trophozoit EM $50.000 \mathrm{x}$

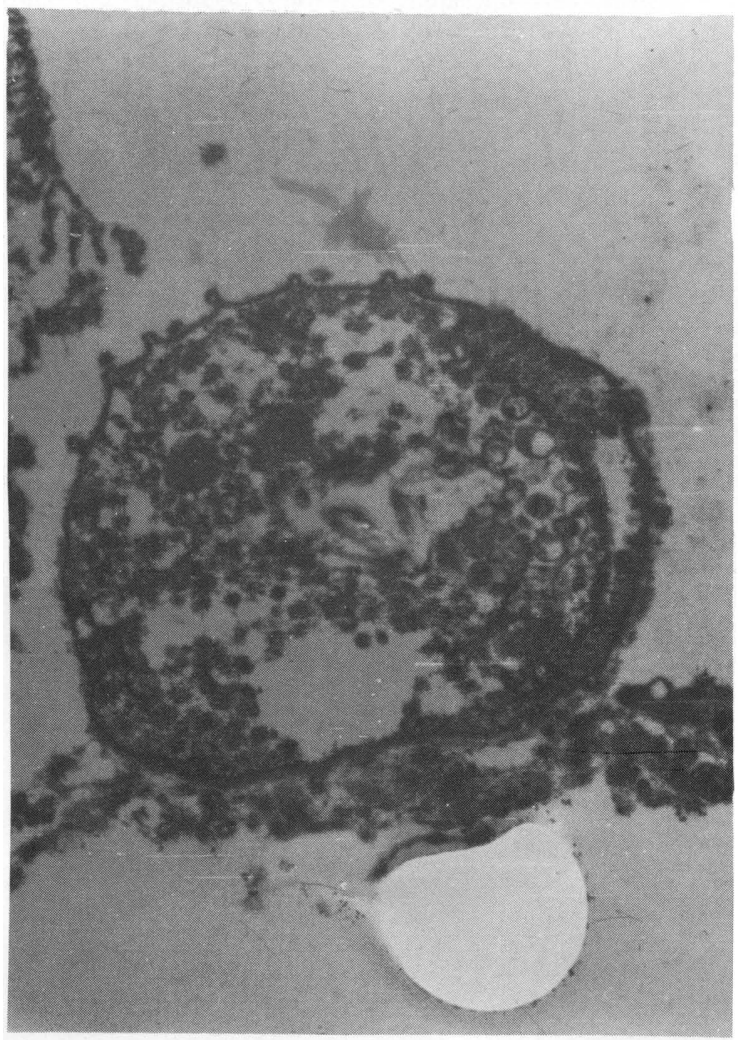

JFig. 5 - Cryptosporidium, sp macrogametocyte. EM $21.000 \mathrm{x}$ agree that this is an easily overlooked infection when one is not familiar with the morphology of the agent we reviewed 66 other autopsy cases from undernourished children with acute diarrhea with or without Pneumocystis carinii and/ or cytomegalovirus infections. No other case of cryptosporidiosis was found.

Immunodeficiency was diagnosed as prima ry disease in our patient although there were no supportive laboratory data. Our morpnological diagnosis was based on the histological findings of lymphoid depletion and multiple opportunistic infections. This feature could be related to $\operatorname{AIDS}^{8}$ but there was no familial history and since she was a small child we could not exclude the possibility of congenital immunodeficiency ${ }^{9}$. Nevertheless the absence of fibrosis and structural change in thymus could be interpreted as a consequence of undernourishment and stress.

The aim of this paper is to present another Brazilian case of cryptosporidiosis stressing the histological features at autopsy and to call attention to the need of proper fixation of the intestines to provide the maintenance of intestinal villous mucosa necessary to the identification of the parasite.

Cryptosporidium sp must be considered as a possible etiology for an acute diarrhea mainly if the patient is immunodeficient. It may be cause of sporadic diarrhea in developed as well as in developing countries; usually this diarrhea is associated with fever, differing from diarrheas caused by other protozoans ${ }^{5}$. Mild to moderate intestinal villous atrophy may be found in association to this infection.

The source of infection seems to be the stool of infected animals but BOGAERTZ et al ${ }^{1}$ described a case without any contact with animals; they believe that people, food and other sources may play a role in transmission of oocysts.

\section{RESUMO}

Criptosporidiose intestinal associada a infecções por Pneumocystis carinii, cytomegalovirus e Candida sp. 
COELHO, K. I. R.; MAEDA, S. A. \& MARQUES, M. E. A. - Intestinal cryptosporidiosis. Association with Pneumocystis carinii, cytomegalovirus and Candida sp. infections. Rev. Inst. Med. trop. São Paulo, 29:323-326, 1987.

Trata-se de apresentação de um caso de criptosporidiose intestinal diagnosticada histologicamente em material de autópsia.

A paciente era uma criança de 5 meses, internada com diarréia aguda grave, associada a pneumonia por Pneumocystis carinii, sialadenite citomegálica e candidiase oral e cutânea. A presença de infecções oportunísticas múltiplas indicaram o diagnóstico de imunodeficiência.

Cryptosporidium sp é uma possibilidade etiológica para diarréias agudas em pacientes imunodeprimidos ou imunocompetentes e deve ser procurado em material de autópsia quando nāo diagnosticado "in vivo".

\section{REFERENCES}

1. BOGAERTZ, J.; LEPAGE, P.; ROUVROY, D. \& VANDE PITTE, J. - Cryptosporidium sp, a frequent cause of diarrhea in Central Africa. J. clin. Microbiol., 20: 874-876, 1984.

2. GHIAMPI, N. P.; SUNDBERG, R. D.; KLOMPUS, J. P. \& WILson, A. J. - Cryptosporidial enteritis and Pneumocystis pneumonia in a homossexual man. Hum. Path., 14: 734:737, 1983.

3. CURENT, W. L.; REESE, N. C.; ERNST, J. V.; BAILEY, W. S.; HEYMAN, M. B. \& WEINSTEIN, W. M. - Human cryptosporidiosis in immunocompetent and imunodeficient persons. New Engl. J. Med.; 308: 1252-1257, 1983.
4. LOUREIRO, E. C. B.: LINHARES, A. C. \& MATA. L. Acute diarrhoea associated with Cryptosporidium sp in Belem, Brazil. Rev. Inst. Med. trop. S. Paulo, 28: 138-140, 1986

5. MATA, L. - Cryptosporidium and other protozoa in diar rheal disease in less developed countries. Pediat. infect. Dis., 5 (Supplement): S117-S130, 1986.

6. MILLER, R. A.; WASSERHEIT, J. N.; KIRIHARA, J. \& COYLE, M. B. - Detection of Cryptosporidium oocysts in sputum during screening for mycobacteria. J. clin. Microbiol., 20: 1192-1193, 1984.

7. REESE, N. C.; CURRENT, W. L.; ERNST, J. V. \& BAILEY, W. S. - Cryptosporidiosis of man and calf. A case report and results of experimental infections in mice and rats Amer. J. trop. Med. Hyg., 31: 226-229, 1982.

8. REICHERT, C. M.; O'LEARY, T. J.; LEVENS, D. L.; SIMRELL; C. R. \& MACHER, A. M. - Autopsy pathology in the acquired immunodeficiency syndrome. Amer. J. Path., 112: 357-382, 1983.

9. ROGERS, M. F. - AIDS in children: a review of the clinical, epidemiologic and public health aspects. Pediat. Infect. Dis., 4: $230-236,1985$.

10. WEIDERMANN, B. L.; KAPLAN, S. L. \& MARINO, B. - Prevalence and significance of cryptosporidiosis in children. Pediat. infect. Dis., 4: 292-293, 1985.

11. WEIKEL, C. S.; JOHNSTON, L. I.; DE SOUZA, M. \& GUERRANT, R. L. - Cryptosporidiosis in northeastern Brazil. Association with sporadic diarrhea. J. infect. Dis., 151: $963-965,1985$

Recebido para publicação em 02/12/86. 